\title{
Development and Application of a Multiplex Marker Assay to Detect PVY Resistance Genes in Solanum tuberosum
}

\author{
Gregory L. Elison ${ }^{1} \cdot$ Darren G. Hall ${ }^{1} \cdot$ Richard G. Novy $^{1} \cdot$ Jonathan L. Whitworth $^{1}$ (D)
}

Published online: 8 May 2020

(C) The Author(s) 2020

\begin{abstract}
Potato virus $Y$ (PVY) is a major pathogen affecting potato production worldwide. Three independent genes ( $R y_{\text {adg, }} R y_{\text {sto, }}$, and $R y_{c h c}$ ) conferring genetic resistance to all known strains of the virus are currently utilized by breeding programs to develop potato varieties containing extreme resistance to infection by PVY. These resistance genes are typically detected using primers specific for the generation of markers closely-linked to the resistance genes. In recent years there have been attempts to develop a multiplex PCR assay for all resistance genes, but all current published methods either omit at least one resistance gene or are unnecessarily complex and therefore difficult to incorporate successfully for marker-assisted selection. We have developed an assay which tests for the presence of all three sources of resistance in a single, easy to use PCR protocol. The multiplex PCR assay was applied to potato varieties, second-field year breeding germplasm, and a selection of test crosses having progeny segregating for multiple resistance genes to validate the methodology for use in marker-assisted selection in potato breeding programs.
\end{abstract}

\section{Resumen}

El virus Y de la papa (PVY) es un patógeno importante que afecta la producción de papa en todo el mundo. Actualmente se están utilizando tres genes independientes (Ryadg, Rysto, y Rychc) que confieren resistencia genética a todas las variantes conocidas del virus, por los programas de mejoramiento, para desarrollar variedades de papa que contengan resistencia extrema a la infección por PVY. Estos genes de resistencia se les detecta típicamente usando iniciadores específicos para la generación de marcadores estrechamente ligados a los genes de resistencia. En años recientes han habido intentos para desarrollar un ensayo múltiple de PCR para todos los genes de resistencia, pero todos los métodos publicados actualmente, ya sea que omitan por lo menos un gen de resistencia, o son complejos innecesariamente y por lo tanto difíciles de incorporar con éxito para la selección asistida con marcadores. Los ensayos prueban para la presencia de las tres fuentes de resistencia en un protocolo único, fácil de usar, de PCR. El ensayo múltiple de PCR se aplicó a variedades de papa, en germoplasma de mejoramiento en segundo año de campo, y una selección de cruzas de prueba con progenie segregante para genes de resistencia múltiple, para validar la metodología a usarse en una selección asistida por marcadores en programas de mejoramiento de papa.

Keywords Potato virus Y $\cdot$ Virus resistance $\cdot$ Multiplex marker assay

\section{Introduction}

One of the most widespread and damaging potato viruses challenging growers today is Potato virus $Y$ (PVY) which has a worldwide distribution and may cause yield losses of up to $70 \%$ (Karasev and Gray 2013). Infected plants usually

Jonathan L. Whitworth

Jonathan.Whitworth@usda.gov

1 U. S. Department of Agriculture, Agricultural Research Service (USDA-ARS), Aberdeen Research \& Extension Center, Aberdeen, ID 83210, USA produce lower quality tubers, further harming the overall harvest and associated economic returns for growers (Karasev and Gray 2013). PVY is a non-persistently transmitted virus with very quick (seconds) acquisition and transmission times (MacKenzie et al. 2014). Use of pesticides alone to prevent transmission of the virus have proved ineffectual (MacKenzie et al. 2014), although recent studies with crop oil and insecticides applied in seed crops on a routine schedule (e.g. every 4-5 days) have shown reduction in PVY infections (MacKenzie et al. 2017). A more cost-efficient and environmentally friendly approach is to develop potato varieties with genetic resistance to the disease (Solomon-Blackburn and Barker 2001). To date, three resistance loci have been 
identified which confer extreme resistance (ER) to PVY in potato plants, meaning that they confer high levels of resistance to all strains of the virus (Gebhardt and Valkonen 2001). These are thought to originally derive from S. tuberosum ssp. andigena $\left(R y_{\text {adg }}\right)$ (Munoz et al. 1975), S. stoloniferum $\left(R y_{\text {sto }}\right)$ (Ross 1958), and $S$. chacoense (Ry chc) (Asama et al. 1982 ) and are found on chromosomes XI (Hämäläinen et al. 1997), XII (Flis et al. 2005; Song et al. 2005), and IX (Hosaka et al. 2001) respectively. All have been mapped to a sufficient degree of precision to allow the creation of useful genetic markers (Kasai et al. 2000; Mori et al. 2012; Song and Schwarzfischer 2008).

These markers are of considerable importance to breeders because they allow selection of resistant offspring from PVY resistant parent(s) at an early stage in the breeding program where sufficient breeder seed is not yet available for replicated virus testing in the field for response to infection by PVY. At the USDA-ARS, Aberdeen, ID breeding program, second field-year material (12-hill plots) with at least one ER parent are routinely tested for the presence of PVY ER markers during the summer to allow informed decisions to be made while selecting in the field in the fall. However, once a program has a large enough number of crosses in its pipeline, testing for even a single genetic marker can become increasingly laborious and time consuming. As such, attempts have been made to simplify the testing process by combining different markers associated with virus resistance into a single PCR protocol (Herrera et al. 2018; Mori et al. 2011; Naderpour and Sadeghi 2018). These are known as multiplex marker tests and while simple in theory, the potential for different primers to interact in unforeseen ways increases drastically as more primers are introduced.

Multiple successful assays have been developed which combine PVY resistance markers and resistance markers to other diseases such as potato virus $\mathrm{X}$ or late blight (Mori et al. 2011; Naderpour and Sadeghi 2018), however none of these detect all three sources of extreme resistance to PVY. Most recently, there have been two papers from a research group in Russia which outline a method to detect eight separate resistance markers in a single assay, including all three known PVY sources (Rogozina et al. 2019; Saynakova et al. 2018). However, this generates many amplification products which are so close in size that the results cannot be analyzed without specialized equipment. This is not always available to breeding programs and is significantly more expensive to analyze per sample than a PCR run on an agarose gel. As such, there is still a need for an inexpensive and simple multiplex marker test for PVY resistance which can identify all three extreme resistance loci in a single assay. In this manuscript, we demonstrate the creation and reliability of such a test with its application in the screening of our 12-hill virus resistant selections in 2019. We also applied the multiplex assay to the progeny of crosses between parents with different resistance sources to aid breeding efforts in the pyramiding of genes for ER. This inexpensive and easy to use multiplex protocol will be of great use to any program which wants to conduct PVY marker testing for ER and will facilitate the development of PVY-resistant potato varieties.

\section{Materials and Methods}

\section{Tissue Harvesting}

To extract DNA from leaf tissue, approximately $0.4 \mathrm{~g}$ was collected and placed in a $2.0 \mathrm{ml}$ Omni International reinforced microcentrifuge tube containing $3-2.8 \mathrm{~mm}$ ceramic beads. Leaf samples were collected from plants in a field grown seed increase of the ARS-Aberdeen potato breeding program. Named varieties that were used in this study were previously characterized within the Aberdeen potato breeding program for the presence of PVY-resistance markers: 1) No markers: Yukon Gold and Shepody; 2) ADG+: Reiche and Tacna; 3) STO+: Castle Russet and Ursus; 4) CHC+: Saikai 35; 5) Not characterized: Sora.

Leaf samples were also collected from 306 breeding clones in 2019, representing second year 12-hill plots of the Aberdeen potato breeding program which represent all material from that field with at least one parent known to be PVY resistant. Samples collected from the field were flash frozen in liquid nitrogen and stored at $-80{ }^{\circ} \mathrm{C}$ until DNA extraction.

To test for the segregation of markers in crosses with a resistance gene parent, true potato seed was germinated in seedling flats containing a 50/50 mix of vermiculite and perlite. Seedling flats were soaked in a solution containing 1 teaspoon Miracle Grow and $5 \mathrm{ml}$ Baicor chelated iron $(0-0$ 1) per gallon. Flats were covered and allowed to germinate. When plantlets were approximately $2.5 \mathrm{~cm}$ tall, each entire plant was placed into a microcentrifuge tube, flash frozen in liquid nitrogen, and stored at $-80{ }^{\circ} \mathrm{C}$ until DNA extraction. Crosses consisted of 100 plants from each of: Family 1: A12305-16 (ADGSTO) x A93575-4 (ADG); Family 2: PA92A08-17 (STO) x PALB03016-6 (CHC); Family 3: A11720-2 (ADG) x PALB03016-6 (CHC).

\section{Markers and DNA Extraction}

Development of a multiplex PCR assay with the RYSC3 (Kasai et al. 2000) (ADG), YES3A (Song and Schwarzfischer 2008) (STO), and RY186 (Mori et al. 2012) (CHC) primer pairs was done using polymerase RedTaq available from Sigma (Table 1). DNA extraction was conducted using the Qiagen DNeasy Plant Mini Kit with modifications as follows. 500 ul Buffer AP 1, 3 ul RNase A, 150 ul Buffer P3, 650 ul sample applied to the QIAshredder mini spin column, $550 \mu \mathrm{l}$ of the flow through recovered, $825 \mu \mathrm{l}$ Buffer AW2, $50 \mu \mathrm{l}$ Buffer AE for 1st elution, 
Table 1 PCR components for the multiplex assay

\begin{tabular}{ll}
\hline Reagent & Quantity $(\mu \mathrm{L})$ \\
\hline 10x PCR Buffer & 2.5 \\
dNTPs $(10 \mathrm{mM})$ & 0.5 \\
RedTaq & 1.25 \\
RYSC3-F $(10 \mu \mathrm{M})$ & 0.5 \\
RYSC3-R $(10 \mu \mathrm{M})$ & 0.5 \\
YES3A-F $(10 \mu \mathrm{M})$ & 0.25 \\
YES3A-R $(10 \mu \mathrm{M})$ & 0.25 \\
Ry186-11 $(10 \mu \mathrm{M})$ & 1.25 \\
RY186-12 $(10 \mu \mathrm{M})$ & 1.25 \\
Sample DNA $($ variable $)$ & 0.75 \\
H 2 O (variable $)$ & 16 \\
Total & 25 \\
\hline
\end{tabular}

and another $25 \mu \mathrm{l}$ for the 2 nd elution. Sample concentration was checked by a nanodrop and stored at $-20{ }^{\circ} \mathrm{C}$. PCRs were prepared as detailed in Table 1 and run with the following protocol: $1.95^{\circ} \mathrm{C}$ for $5^{\prime}, 2.94^{\circ} \mathrm{C}$ for $30^{\prime \prime}, 3.53^{\circ} \mathrm{C}$ for $20^{\prime \prime}, 4$. $68^{\circ} \mathrm{C}$ for $45^{\prime \prime}, 5$. repeat steps $2-434 \mathrm{X}, 6.68^{\circ} \mathrm{C}$ for $5^{\prime}, 7.4^{\circ} \mathrm{C}$ indefinitely. RedTaq (at 1 unit / microliter) and PCR buffer are both available from Sigma while we obtained dNTP mix from New England Biolabs. The primers used were developed in previous manuscripts by varying groups, were used without sequence changes, and are given in $5^{\prime}$ to $3^{\prime}$ order in Table 2. PCRs were generally run on a $1.5 \%$ agarose gel for $45 \mathrm{~min}$ at a voltage of $155 \mathrm{v}$ in $\mathrm{SB}$ (sodium borate) buffer, but other settings can be used.

\section{PCR Conditions}

Initial testing was carried out using $0.75 \mu$ of undiluted DNA following extraction. This gives a wide range of DNA concentrations $(25-500 \mathrm{ng} / \mu \mathrm{l})$ which were tested. This variance does not significantly change the results of the assay and even samples with as low as 10-20 ng/ $\mu$ l may be utilized without concern when examining samples with a single resistance marker band. Samples containing multiple resistance bands are more sensitive to the concentration of input DNA. To determine the ideal DNA input for these circumstances, samples with both a STO and CHC marker band were titrated from $5 \mathrm{ng}$ to $200 \mathrm{ng}$ of total DNA. Based on these results, 25-50 ng of total DNA was used for all experiments unless otherwise specified.

\section{Virus Field Tests}

For field virus screening trials, three replications of five hill plots of each entry were grown in a randomized complete block design. Every third row ('spreader row') consisted of Russet Burbank interplanted with PVY-infected source plants. This row also contained Potato leafroll virus infected plants for a separate assay. Standard fertility and irrigation practices recommended for Russet Burbank were used. Appropriate control varieties were included each year. Clones screened were assumed to be free of PVY at the beginning of each growing season based on negative ELISA testing prior to tuber harvest the previous summer. Plants were inoculated when they were an average height of $15-30 \mathrm{~cm}$. Plants were inoculated by using a spray gun connected to an air compressor set to deliver $\sim 689 \mathrm{kPa}$. Infected sap collected from $\mathrm{PVY}$ positive plants grown out from the year prior was put in a phosphate buffer $\left(0.1 \mathrm{M} \mathrm{K}_{2} \mathrm{HPO}_{4}, 0.025 \mathrm{M}\right.$ $\mathrm{KH}_{2} \mathrm{PO}_{4}, \mathrm{pH} 7.5$ ). For application a $1 \mathrm{~L}$ reservoir spray gun with $\sim 60 \mathrm{mg} 320$ grit carborundum was added to the sap. Each plant was sprayed until wet. The ratio of fresh leaf tissue was $1 \mathrm{~g} / 5 \mathrm{ml}$ buffer. This mixture was prepared the day before and the infected sap was kept at $4{ }^{\circ} \mathrm{C}$ overnight and then transported to the field on ice. PVY infected sap used each year contained PVY ${ }^{\mathrm{O}}$ and PVY necrotic strains collected from the field. Green peach aphids (Mysus persicae (Sulzer)) were released into 'spreader' rows in late June each year, about 50 days after planting allowing PVY to be transmitted to the test plots. At harvest, ten tubers from each plot were collected and stored for post-harvest virus testing. Typically, in late February to early March after dormancy break, a $3.5 \mathrm{~cm}$ sized scoop was excised from each tuber and planted in the greenhouse. When the plants were $\sim 20 \mathrm{~cm}$, a leaflet was taken from each plant and individually tested with ELISA for PVY, using the monoclonal antibody PVYall from SASA, in order to calculate percent infection from a total of 30 plants of each entry across the three replicates.
Table 2 Primer sequences used in the multiplex assay

\begin{tabular}{llll}
\hline Primer Name & Sequence $\left(5^{\prime}\right.$ to $3^{\prime}$ ) & Marker & Citation \\
\hline RYSC3-F & ATACACTCATCTAAATTTGATGG & ADG & (Kasai et al. 2000) \\
RYSC3-R & AGGATATACGGCATCATTTTTCCGA & ADG & (Kasai et al. 2000) \\
YES3A F & TAACTCAAGCGGAATAACCC & STO & (Song and Schwarzfischer 2008) \\
YES3A R & AATTCACCTGTTTACATGCTTCTTGTG & STO & (Song and Schwarzfischer 2008) \\
RY186-11 & TGGTAGGGATATTTTCCTTAGA & CHC & (Mori et al. 2012) \\
RY186-12 & GCAAATCCTAGGTTATCAACTCA & CHC & (Mori et al. 2012) \\
\hline
\end{tabular}




\section{Results}

\section{Assay Development and Initial Testing}

The combination of primers RYSC3, YES3A, and RY186 gave a robust indication of the presence of any combination of markers present in a DNA sample. The bands of varying intensity of the right number of base pairs were specific for each of the markers. Rarely, some bands were lighter than usual, which was attributed to excessive quantities of DNA. When the correct DNA amount is used, the presence of a marker nearly always gave a strong band. In general, $0.75 \mu \mathrm{l}$ of undiluted DNA following extraction $(\sim 25-500 \mathrm{ng} / \mu \mathrm{l})$ worked well except in a few cases described below. In the absence of any of these markers, no band appeared, and the lane was empty. An example of all possible marker combinations is shown in Fig. 1. The DNA input for the PCR shown in the final lane is derived from a combination of multiple samples as no variety or breeding line was available at the time that possessed all three known resistance sources.

When the appropriate marker was present RYSC3 gave a band of 321 bp (Kasai et al. 2000), YES3A gave a band of 341 bp (Song and Schwarzfischer 2008), and RY186 gave a band of 587 bp (Mori et al. 2012). This resulted in an easily distinguished $\mathrm{CHC}$ band and an
ADG band close to the STO band. Further resolution of the ADG and STO bands was obtained by a $1.5 \%$ agarose gel run at $155 \mathrm{v}$ for at least $45 \mathrm{~min}$, allowing a clear doublet when both were present as in Fig. 1, lane 6. The difference between the ADG and STO bands was seen after $30 \mathrm{~min}$ and became very clear after $45 \mathrm{~min}$. If higher resolution is required, a higher percentage gel and/or a longer running time can be used, but in general these steps were not necessary. When a light band was present in a sample containing multiple resistance markers, using $50 \mathrm{ng}$ of input DNA alleviated the problem caused by adding too much input DNA.

\section{Testing of Named Varieties with Known Sources of Resistance}

Using a subset of varieties with known resistances, the assay correctly identified the resistance source (or lack thereof) for all tested named varieties. Correlation of marker presence with virus resistance, is shown in Table 3 with existing data from virus field trials on resistant and susceptible varieties. All markers were easily identified and correspond to the expected genotype of the named variety. No $R y$ marker for the Slovenian variety Sora (Dolničar and Rudolf Pilih 2012) was present, although Sora has been phenotypically tested to have ER to PVY.
Fig. 1 Multiplex marker range of possible results. All samples contained $\sim 50 \mathrm{ng}$ of input DNA. The gel shown is $1.5 \% \mathrm{w} / \mathrm{v}$ agarose and was run for 45 minutes at $155 \mathrm{v}$ with the following configuration: Lane 1: 2-log ladder from New England Biolabs (NEB); Lane 2: No marker; Lane 3: ADG marker; Lane 4: STO marker; Lane 5: CHC marker; Lane 6: ADG marker and STO marker; Lane 7: ADG marker and $\mathrm{CHC}$ marker; Lane 8: STO marker and CHC marker; Lane 9: ADG marker and STO marker and $\mathrm{CHC}$ marker. Lane numbers are given at the top of each image

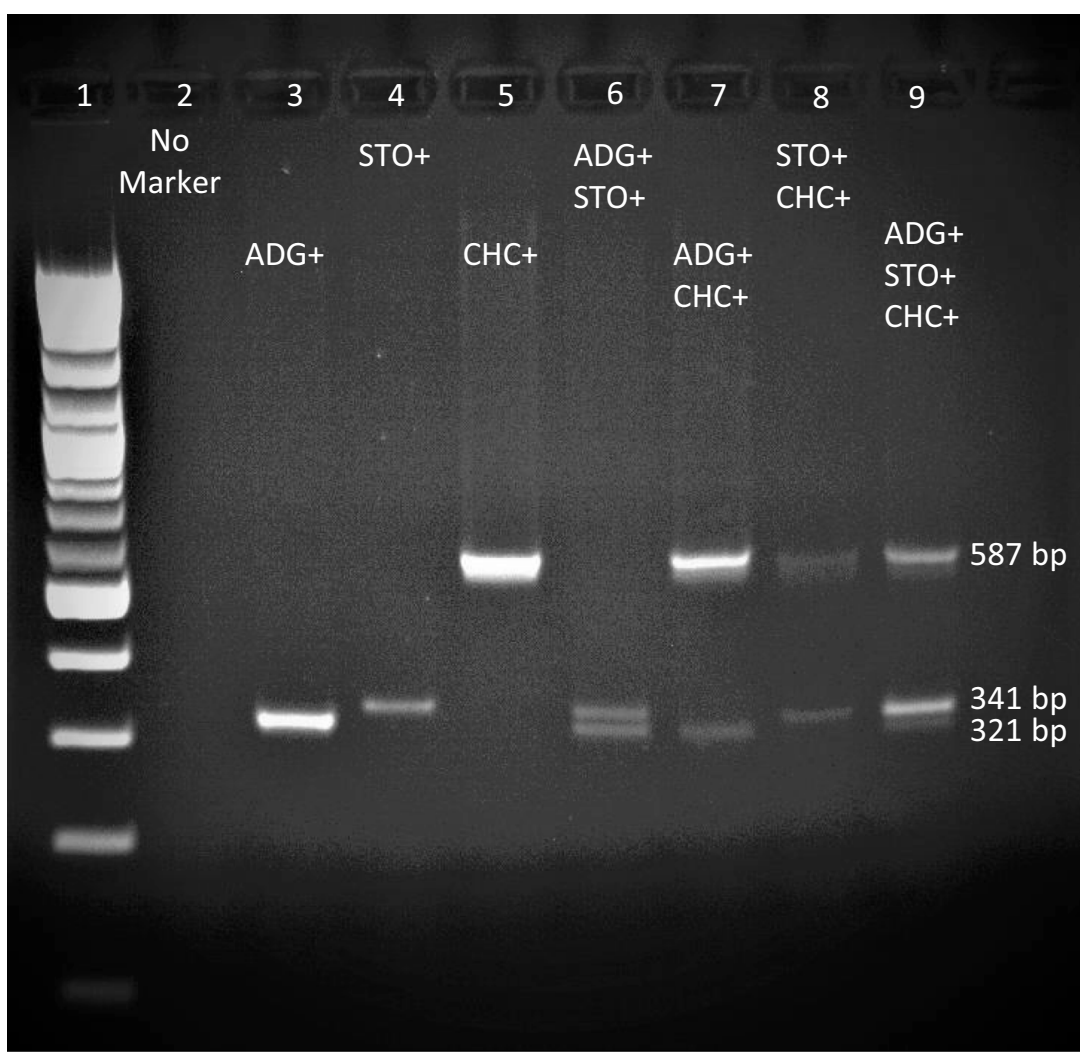


Table 3 Incidence of PVY infection for selected varieties in replicated field trials, Kimberly, Idaho

\begin{tabular}{llllll}
\hline Variety & Marker & 2009 & 2010 & 2014 & 2015 \\
\hline Yukon Gold & None & $41 \% *$ & $93 \%$ & $97 \%$ & $100 \%$ \\
Shepody & None & - & $90 \%$ & $100 \%$ & $100 \%$ \\
Reiche & ADG & $0 \%$ & $0 \%$ & - & - \\
Tacna & ADG & $0 \%$ & $0 \%$ & - & - \\
Castle Russet & STO & - & - & $0 \%$ & $0 \%$ \\
Ursus & STO & - & - & - & $0 \%$ \\
Saikai 35 & CHC & - & - & $0 \%$ & $0 \%$ \\
Sora & None & - & - & - & $0 \%$ \\
\hline
\end{tabular}

$(-)$ indicates that a variety was not tested in a given year

*Incidence is given as a percentage. The value is an average of the infection rate of a total of 30 harvested tubers of each entry that were tested using ELISA. $100 \%$ means all plants originating from harvested tubers were positive for PVY based on ELISA

\section{Testing of Breeding Material from the Field}

To assess the efficacy of this multiplex assay in a large potato breeding program it was applied to all 12-hill individuals grown in Aberdeen ID in 2019 which had at least one parent with a resistance marker or with known resistance to PVY. Of a total of 306 12-hill individuals, 78 had pedigrees with an ADG parent, 183 with a STO parent, 49 with a CHC parent, and 38 had at least one parent with resistance to PVY which did not display a marker. The numbers do not add to 306 due to the existence of crosses between parents containing different markers. Of these, 38 individuals contained an ADG marker, 81 contained a STO marker, and 26 contained a CHC marker. Crucially, no bands were detected which contradicted the expected results based on parentage, resulting in a very low false positive rate. In addition, this confirms the ability of the assay to assess large quantities of material quickly and efficiently.

\section{Testing of Crosses Containing Multiple Resistance Markers}

Due to the relative lack of progeny examined in the 2019 12-hill selections which contained multiple markers in the same cross, three families were chosen to give different combinations of resistance markers and to have a mix of expected segregation ratios (Family 1). The observed ratios of progeny from three families with and without markers associated with $R y$ genes fit expected ratios with no indications of aberrant segregation (Table 4). This holds for crosses containing different resistance markers (Families 2 and 3 ) and for crosses containing multiple copies of the same resistance marker (Family 1). The multiplex assay provided valid results in the assessment of the segregation of markers associated with three $R y$ loci in segregating potato populations.

\section{Discussion}

A multiplex assay was developed with low cost $(\sim \$ 0.30 /$ sample after extraction) and high rapidity which allows the simultaneous analysis of the presence of markers associated with three genes conferring ER to PVY in potato breeding clones and varieties. The cost estimate is derived from the combined costs of all reagents for a single sample. Previous methods required individual tests for each PVY marker which slowed the process of marker-assisted selection in potato breeding programs, especially once the total number of tests exceeds the number that could fit into a single 96 -well plate. A potential drawback to individual testing approaches is that it also hinders the identification of any unexpected resistance sources whether they are due to mislabeling or have never been genotyped previously. In addition, the assay speeds up and simplifies the basic selection of field plants by providing a single test that is easily applied to all desired material before field selections.

While undiluted DNA input works well for analysis of samples containing a single resistance marker, we have found that a narrow range of 25-50 ng of input DNA is suitable for analysis of samples containing multiple resistance markers. While it may seem counterintuitive, additional DNA may cause one of the expected bands to become faint or harder to see in comparison. As such, we recommend a DNA concentration of $50 \mathrm{ng}$ for optimal viewing. This is less critical when attempting to view a single band, but $50 \mathrm{ng}$ is adequate to see single bands as well, so our recommendation of $50 \mathrm{ng} / \mathrm{pcr}$ tube (or $0.75 \mu \mathrm{l}$ of $67 \mathrm{ng} / \mu \mathrm{l} \mathrm{DNA}$ ) can be applied to all samples.

Use of this multiplex protocol in a breeding program will identify markers present in progeny, regardless if they are $R y_{\text {sto }}$ or $R y_{\text {adg }}$ which are more closely aligned with one another following gel electrophoresis relative to the marker for $R y_{c h c}$. The $\mathrm{CHC}$ band is easily distinguishable from the ADG and STO bands, but the ADG band and STO band are only $20 \mathrm{bp}$ apart and can be hard to distinguish in a low-resolution gel. We attempted several different known markers for ADG and STO but were unable to find conditions under which both functioned correctly and in which the bands were farther apart. Under standard gel-running conditions as previously described, individuals with sufficient experience in gel interpretation can confidently identify the different bands. If there is any concern, we recommend the use of positive controls, longer run times on a high percentage gel, and consideration of the parental resistance sources.

Because all populations in this study are considered to be autotetraploid, we take chromatid segregation (i.e., double reduction occurs following crossing over occurring between 
Table 4 Segregation of Ry markers in progeny of families containing multiple resistance sources

\begin{tabular}{llll}
\hline & Family 1 & Family 2 & Family 3 \\
\hline Female & $\begin{array}{l}\text { A12305-16 } \\
\text { (ADGSTO) }\end{array}$ & PA92A08-17 (STO) & A11720-2 (ADG) \\
Male & A93575-4 (ADG) & PALB03016-6 & PALB03016-6 \\
& 40 & (CHC) & (CHC) \\
Resistance (ADG) & 16 & 0 & 27 \\
Resistance (STO) & 0 & 27 & 0 \\
Resistance (CHC) & 33 & 27 & 27 \\
Resistance (ADG + STO) & 0 & 0 & 0 \\
Resistance (ADG + CHC) & 0 & 0 & 17 \\
Resistance (STO + CHC) & 11 & 18 & 0 \\
No Resistance & 100 & 28 & 29 \\
Total & 89 & 100 & 100 \\
Percent Resistant & $73: 71^{\&}$ & 72 & 71 \\
Marker 1* observed vs expected & 0.659 & $45: 47$ & $44: 47$ \\
Marker 1 $\chi^{2}$ P value & Fail to Reject & 0.689 & 0.548 \\
Marker 1 Verdict & $49: 47$ & Fail to Reject & Fail to Reject \\
Marker 2 observed vs expected & 0.689 & $45: 47$ & $44: 47$ \\
Marker 2 $\chi^{2}$ P value & Fail to Reject & 0.689 & 0.548 \\
Marker 2 Verdict & Fail to Reject & Fail to Reject \\
\hline
\end{tabular}

*: In the case of the first cross Marker 1 is ADG and Marker 2 is STO. For the other crosses: Marker 1 refers to the marker deriving from the female parent and Marker 2 refers to the marker deriving from the male parent

\&: Expected values are based on chromatid segregation with an expected ratio of $0.87: 1$ rather than chromosome segregation with an expected ratio of 1:1 to take possible double reduction into account
Ry genes and the centromere) into account when determining expected segregation rather than simply using chromosome segregation (no crossing over expected between the centromere and Ry genes) (Rieger et al. 1991). As such, we expect that a cross between a parent simplex for $R y$ and a nullplex parent should give a $0.87: 1$ ratio for chromatid segregation rather than the 1:1 ratio expected for chromosome segregation (Table 4: Families 2 and 3 with independent segregation assumed between $R y$ genes, and for $R y_{\text {sto }}$ of Family 1). We use the estimate of $0.87: 1$ due to reports in the literature of the three $R y$ genes being distal to the centromere (Hämäläinen et al. 1998; Sato et al. 2006; Song et al. 2005) which results in a higher theoretical difference from a $1: 1$ ratio than if the genes were closer to the centromere. Similarly, in the case of a cross between two simplex parents, we expect a 2.5:1 ratio rather than a 3:1 ratio for chromatid and chromosome segregation, respectively (Family 1 for $R y_{a d g}$ ). Admittedly, this does not cause a large change in expected ratios for families of no more than 100 individuals, with both ratios varying inconsequentially from one another. Comparisons of expected versus observed for the presence or absence of molecular markers in the populations did however most closely fit that for chromatid segregation. Based on our findings and reports in the literature regarding chromosome location of the $R y$ genes, calculation of $\chi^{2} P$ values in Table 4 utilizes ratios expected for chromatid segregation with each marker analyzed individually under the assumption they segregate independently since they are on different chromosomes.

It should be noted that marker-based selection does not work on all varieties of potato. Of the 38 individuals in the 2019 12-hill descended from resistant parents without markers, ten came from families in which only one or two clones were selected, and so the source of their resistance cannot be confirmed. However, the remaining 28 show no markers whatsoever and descend from one of two resistant parents. Eleven descend from clone A06862-11VR which does not show any marker, but which is itself descended from a STO+ virus resistant parent and was shown to possess ER to PVY in our field trials. Thus, is it likely that a meiotic event separated the STO gene from its marker in this clone and so neither it nor its progeny show a marker. The marker used is expected to be roughly 1 centimorgan away from $R y_{\text {sto }}$ (Song et al. 2005; Song and Schwarzfischer 2008) and as such, it is expected that such an event should occur somewhere in the range of $1 \%$ of STO crosses to a susceptible parent and we believe that this is one such event. It is also possible that the resistance could originate from a novel Ry gene, but the ancestry of the clone makes this unlikely.

The remaining 17 progeny descend from one of two Slovenian parents called Bistra and Sora (Dolničar and Rudolf Pilih 2012) which have been shown to possess ER to PVY in our field trials. Both are descended from a Dutch 
parent called Santé, which has also been shown to have ER to PVY without any reported resistance markers (Cernák et al. 2008; Flis et al. 2005). It is likely that they inherited this trait, and our assay agrees with several other previous studies (Cernák et al. 2008; Flis et al. 2005; Heldák et al. 2007) in being unable to ascribe any marker band to the variety. It is likely that their parent Santé also experienced a meiotic event to separate whatever resistance gene it possesses from its marker, but it may also represent a separate source of resistance. Until this issue is resolved, and a marker is developed which could be used for these varieties, their progeny will need to be tested for virus resistance directly in the absence of genetic testing. We would still expect resistance to segregate in a 1:1 manner even though this cannot be tested until the crosses are ready for field virus tests. It is expected that all resistance markers for PVY should have at least a $1 \%$ chance of separating from their resistance gene in each progeny. Very recently, $R y_{\text {sto }}$ has been tentatively identified (Grech-Baran et al. 2019) but the distinguishing mutations of the resistant allele are still unknown as are the identities of $R y_{\text {adg }}$ and $R y_{c h c}$. Once these are determined, it will be straightforward to confirm any potential broken associations between the genes and their markers.

This assay is useful to breeding programs for two major reasons. The first, is that it makes PVY resistance sampling from the field easier and faster. This means that new crosses may be easily examined early in the selection process to ensure that virus resistant plants are moved forward in the program. The second is that breeding programs with a large amount of existing material accumulated over decades may be easily screened for the presence of any PVY resistance markers in a much easier manner than was available previously. In the course of this project, it was discovered that two of our internal breeding clones (PALB0303-1 and PALB030166) contained a CHC resistance marker to PVY which was unexpected at the beginning of the project. The clones had been known to possess PVY resistance in field trials for several years, but the source of their resistance had not previously been determined. These lines were originally bred for late blight resistance at the USDA research station in Prosser, WA, and have been used as parental material in the breeding program for years. Unfortunately, the source of the CHC based resistance will likely never be known as both parents contain crosses with bulked pollen in their background. This is also why these parents had not previously been tested for CHC markers. Our identification of this resistance of a good example of the usefulness of screening existing populations with new assays.

Another interesting possibility is that this allows breeding programs to work toward the production of varieties containing multiple PVY resistance markers. While no $R y$ gene has yet been broken by a viral strain, it is possible that resistant $R y$ varieties will not remain so due to evolution of the virus. The easiest way to counter this is to pyramid divergent PVY resistance genes in future potato varieties. This assay greatly increases the ability to detect, select, and therefore pyramid PVY resistance genes. Pyramiding of $R y$ genes in breeding clones also allows potato breeders to obtain a greater proportion of PVY-resistant progenies in families following hybridizations with PVY-susceptible parents. Currently, we do not know of any named varieties with all three genes for ER to PVY, but tools like this assay allow higher throughput and simplicity in developing varieties with multiple $R y$ genes.

Open Access This article is licensed under a Creative Commons Attribution 4.0 International License, which permits use, sharing, adaptation, distribution and reproduction in any medium or format, as long as you give appropriate credit to the original author(s) and the source, provide a link to the Creative Commons licence, and indicate if changes were made. The images or other third party material in this article are included in the article's Creative Commons licence, unless indicated otherwise in a credit line to the material. If material is not included in the article's Creative Commons licence and your intended use is not permitted by statutory regulation or exceeds the permitted use, you will need to obtain permission directly from the copyright holder. To view a copy of this licence, visit http://creativecommons.org/licenses/by/4.0/.

\section{References}

Asama, K., I. H, M. N, and I. T. 1982. New potato variety "Konafubuki”. Bull Hokkaido Pref Agr Exp Stn 48:75-84.

Cernák, I., K. Decsi, S. Nagy, I. Wolf, Z. Polgár, G. Gulyás, Y. Hirata, and J. Taller. 2008. Development of a locus-specific marker and localization of the Ry sto gene based on linkage to a catalase gene on chromosome XII in the tetraploid potato genome. Breeding Science 58: 309-314.

Dolničar, P., and K. Rudolf Pilih. 2012. Gene bank and potato breeding in Slovenia. Acta Agriculturae Slovenica 99: 377-386.

Flis, B., J. Hennig, D. Strzelczyk-Żyta, C. Gebhardt, and W. Marczewski. 2005. The Ry-f sto gene from Solanum stoloniferum for extreme resistant to potato virus $\mathrm{Y}$ maps to potato chromosome XII and is diagnosed by PCR marker GP122 718 in PVY resistant potato cultivars. Molecular Breeding 15: 95-101.

Gebhardt, C., and J.P.T. Valkonen. 2001. Organization of genes controlling disease resistance in the potato genome. Pages 79-102 in: Annual review of phytopathology.

Grech-Baran, M., K. Witek, K. Szajko, A.I. Witek, K. Morgiewicz, I. Wasilewicz-Flis, H. Jakuczun, W. Marczewski, J.D.G. Jones, and J. Hennig. 2019. Extreme resistance to potato virus Y in potato carrying the Rysto gene is mediated by a TIR-NLR immune receptor. Plant Biotechnology Journal.

Hämäläinen, J.H., K.N. Watanabe, J.P.T. Valkonen, A. Arihara, R.L. Plaisted, E. Pehu, L. Miller, and S.A. Slack. 1997. Mapping and marker-assisted selection for a gene for extreme resistance to potato virus Y. Theoretical and Applied Genetics 94: 192-197.

Hämäläinen, J.H., V.A. Sorri, K.N. Watanabe, C. Gebhardt, and J.P.T. Valkonen. 1998. Molecular examination of a chromosome region that controls resistance to potato $\mathrm{Y}$ and a potyviruses in potato. Theoretical and Applied Genetics 96: 1036-1043.

Heldák, J., M. Bežo, V. Štefúnová, and A. Galliková. 2007. Selection of DNA markers for detection of extreme resistance to potato virus $\mathrm{Y}$ in 
tetraploid potato (Solanum tuberosum L.) F1 progenies. Czech Journal of Genetics and Plant Breeding 43: 125-134.

Herrera, M.R., L.J. Vidalon, J.D. Montenegro, C. Riccio, F. Guzman, I. Bartolini, and M. Ghislain. 2018. Molecular and genetic characterization of the Ry adg locus on chromosome XI from Andigena potatoes conferring extreme resistance to potato virus Y. Theoretical and Applied Genetics 131: 1925-1938.

Hosaka, K., Y. Hosaka, M. Mori, T. Maida, and H. Matsunaga. 2001. Detection of a simplex RAPD marker linked to resistance to potato virus $Y$ in a tetraploid potato. American Journal of Potato Research 78: 191-196.

Karasev, A.V., and S.M. Gray. 2013. Continuous and emerging challenges of potato virus y in potato. Pages 571-586 in: Annual review of phytopathology.

Kasai, K., Y. Morikawa, V.A. Sorri, J.P.T. Valkonen, C. Gebhardt, and K.N. Watanabe. 2000. Development of SCAR markers to the PVY resistance gene RY(adg) based on a common feature of plant disease resistance genes. Genome 43: 1-8.

MacKenzie, T.D.B., M.S. Fageria, X. Nie, and M. Singh. 2014. Effects of crop management practices on current-season spread of potato virus Y. Plant Disease 98: 213-222.

MacKenzie, T.D.B., J. Lavoie, X. Nie, and M. Singh. 2017. Effectiveness of combined use of mineral oil and insecticide spray in reducing potato virus $\mathrm{Y}$ (PVY) spread under field conditions in New Brunswick, Canada. American Journal of Potato Research 94: 70 80.

Mori, K., Y. Sakamoto, N. Mukojima, S. Tamiya, T. Nakao, T. Ishii, and K. Hosaka. 2011. Development of a multiplex PCR method for simultaneous detection of diagnostic DNA markers of five disease and pest resistance genes in potato. Euphytica 180: 347-355.

Mori, K., N. Mukojima, T. Nakao, S. Tamiya, Y. Sakamoto, N. Sohbaru, K. Hayashi, H. Watanuki, K. Nara, K. Yamazaki, T. Ishii, and K. Hosaka. 2012. Germplasm release: Saikai 35, a male and female fertile breeding line carrying Solanum Phureja-derived cytoplasm and potato cyst nematode resistance $(\mathrm{H} 1)$ and potato virus $\mathrm{Y}$ resistance (Ry chc) genes. American Journal of Potato Research 89: 6372 .
Munoz, F.J., R.L. Plaisted, and H.D. Thurston. 1975. Resistance to potato virus $\mathrm{Y}$ inSolanum tuberosum spp.andigena. American Potato Journal 52: 107-115.

Naderpour, M., and L. Sadeghi. 2018. Multiple DNA markers for evaluation of resistance against potato virus $\mathrm{Y}$, potato virus $\mathrm{S}$ and potato leafroll virus. Czech Journal of Genetics and Plant Breeding 54: 30 33.

Rieger, R., A. Michaelis, and M.M. Green. 1991. M. Pages 304-345 in: Glossary of Genetics: Classical and Molecular. Springer Berlin Heidelberg, Berlin, Heidelberg.

Rogozina, E.V., E.V. Terentjeva, E.K. Potokina, E.N. Yurkina, A.V. Nikulin, and Y.I. Alekseev. 2019. Multiplex PCR-based identification of potato genotypes as donors in breeding for resistance to diseases and pests. Sel'skokhozyaistvennaya Biologiya 54: 19-30.

Ross, H. 1958. Inheritance of extreme resistance to potato virus $\mathrm{Y}$ in Solanum stoloniferum and its hybrids with Solanum tuberosum. Proc Third Conf Potato Virus Diseases: 204-211.

Sato, M., K. Nishikawa, K. Komura, and K. Hosaka. 2006. Potato virus Y resistance gene, Rychc, mapped to the distal end of potato chromosome 9. Euphytica 149: 367-372.

Saynakova, A.B., M.S. Romanova, S.N. Krasnikov, O.V. Litvinchuk, Y.I. Alekseev, A.V. Nikulin, and E.V. Terentjeva. 2018. Testing potato collection samples for the presence of genes for resistance to phytopathogens by means of DNA markers. Vavilovskii Zhurnal Genetiki i Selektsii 22: 18-24.

Solomon-Blackburn, R.M., and H. Barker. 2001. Breeding virus resistant potatoes (Solanum tuberosum): A review of traditional and molecular approaches. Heredity 86: 17-35.

Song, Y.S., and A. Schwarzfischer. 2008. Development of STS markers for selection of extreme resistance (Ry sto ) to PVY and maternal pedigree analysis of extremely resistant cultivars. American Journal of Potato Research 85: 159-170.

Song, Y.S., L. Hepting, G. Schweizer, L. Hartl, G. Wenzel, and A. Schwarzfischer. 2005. Mapping of extreme resistance to PVY (Rysto) on chromosome XII using anther-culture-derived primary dihaploid potato lines. Theoretical and Applied Genetics 111: 879-887. 